\title{
A SIMPLE DYE-COUPLING ASSAY FOR EVALUATING GAP JUNCTIONAL COMMUNICATION: THE IMPORTANCE OF TRANSCRIPTION AND TRANSLATION ON THE ESTABLISHMENT OF DYE-COUPLING
}

\section{Robert H. Zidell and Rita Loch-Caruso*}

Toxicology Program, Department of Environmental and Industrial Health, The University of Michigan School of Public Health, 109 S. Observatory, Ann Arbor, MI 481092029

*'To whom correspondence should be addressed

\section{ABSTRACT}

A simple dye-coupling assay has been developed to study gap junctional communication using a uterine cell line. The new dye-coupling assay was found to be of comparable sensitivity to an autoradiographic assay for transfer of radiolabelled nucleotide. To investigate the importance of protein synthesis in the establishment of dye-coupling under the conditions of this assay, cultures were treated with actinomycin-D and cycloheximide to inhibit transcription and translation, respectively. Inhibition of transcription had no significant effect on dye-coupling. The protein synthesis inhibitor, cycloheximide, also had no significant effect on dye-coupling at concentrations up to $1 \mathrm{uM}$, even though protein synthesis was inhibited to $19 \%$ of control.

Key Words: Gap junctions, intercellular junctions, protein inhibitors.

\section{INTRODUCTION}

Gap junctions mediate direct intercellular transfer of low molecular weight substances in a wide variety of cells (Loewenstein, 1981; Larsen, 1983). These communicating junctions have been implicated in many important functions, including the synchronized contraction of uterine smooth muscle during labor (Garfield, 1988). We have developed a rapid in vitro dye-coupling assay to investigate intercellular communication between uterine cells using an established cell line derived from a human uterine leiomyosarcoma, SK-UT-1.

In this dye-coupling assay, dye-donor cells were labeled with both a permanent cell marker, latex beads, 
and a transferable fluorescent dye derived from 5 (and 6)-carboxy-2,7-dichlorofluorescein diacetate (DCCFDA). Donor cells were co-cultured with unlabeled dye-recipient cells, after which transfer of dye from the donors to the recipients was evaluated using an epifluorescence microscope. Parallel experiments with a previously published autoradiographic assay based on transfer of radiolabelled nucleotide demonstrated that the new dyecoupling assay was of comparable sensitivity. Transcription and translation were inhibited with actinomycin-D and cycloheximide, respectively, to determine if the establishment of communicating junctions required protein synthesis. This assay has recently been applied to an embryocarcinoma cell line (Loch-Caruso et al., 1988).

\section{MATERIALS AND METHODS}

Cell Culture. SK-UT-1 cells were obtained from the American Type Culture collection (Rockville, MD) and used between passages 35-75. The SK-UT-1 cell 1 ine was originally isolated from a human mesodermal uterine tumor consistent with a grade III leiomyosarcoma, and is presumably of myometrial origin (Fogh et al., 1977). The cells were maintained in a growth medium containing Eagle's salts (Eagle, 1959), a two-fold enrichment of non-essential amino acids, a 1.5-fold enrichment of vitamins and essential amino acids (except L-glutamine), with the addition of $1 \mathrm{mM}$ sodium pyruvate, $5.55 \mathrm{mM} \mathrm{D-}$ glucose, $14.3 \mathrm{mM}$ sodium chloride, $11.9 \mathrm{mM}$ sodium bicarbonate, and 5\% fetal bovine serum, $\mathrm{pH}$ 7.4. Cultures were periodically checked for the presence of mycoplasma (Chen, 1977).

Chemicals. Actinomycin-D, ethidium bromide and cycloheximide were purchased from sigma chemical (st. Louis, MO). The dye, 5(and 6)-carboxy-2,7-dichlorofluorescein diacetate (DCCFDA), was purchased from Molecular Probes (Eugene, $O R$ ). Radiolabeled uridine and leucine were purchased as sterile aqueous solutions (Amersham, Arlington Heights, IL). Fluorescein-conjugated latex beads (Fluoresbrite carboxylate microspheres, ca. 1 um diameter) were purchased from Polysciences (Warrington, $\mathrm{PA})$. Stock solutions were prepared of actinomycin-D ( $5 \mathrm{mg} / \mathrm{ml}$ in absolute ethanol), DCCFDA (10 $\mathrm{mm}$ in dimethyl sulfoxide) and ethidium bromide $(1 \mathrm{mg} / \mathrm{ml}$ in Dulbecco's phosphate-buffered saline solution (DPBS)), and stored refrigerated. Working solutions were diluted from the stock solutions immediately prior to use. 
Dye-Coupling Assay. Dye-donor cells were grown to near confluence, rinsed with DPBS containing $1 \mathrm{mg} / \mathrm{ml}$ glucose (PBSG), and treated for $4 \mathrm{~h}$ at $37^{\circ} \mathrm{C}$ with fluorescent latex beads in PBSG $\left(1-2 \times 10^{8}\right.$ beads/sq. cm growth surface area). Under these conditions, each donor cell internalized approximately 5-20 beads, which were then retained throughout the experiment. Because the beads were too large to pass through gap junctions, they provided a readily identifiable and permanent marker to distinguish the donor cells from the recipient cells. The cultures were then rinsed free of unincorporated beads with PBSG, and treated for $10 \mathrm{~min}$ with $15 \mathrm{uM}$ DCCFDA in PBSG at $37^{\circ} \mathrm{C}$. DCCFDA is a membrane-permeant, non-fluorescent dye (529.3 MW) that is metabolically activated to a fluorescent and lipophobic state after hydrolysis of the acetate ester linkages (Rotman and Papermaster, 1966). The lipophobic fluorescent dye is retained by many cells for several hours, yet is small enough to pass through gap junctions (Loewenstein, 1981). The two chlorine substitutions make this dye much less sensitive to fluorescent photobleaching than the parent material, 5(and 6)-carboxyfluorescein (unpublished observation). The cultures were rinsed twice with PBSG to remove unincorporated and surface-bound dye, and then rinsed an additional two times with calcium- and magnesium-free Hank's balanced salt solution (CMF-HBSS). Cells were harvested by trypsin digestion, pelleted by low-speed centrifugation, rinsed with medium and resuspended in fresh medium. A sample of the cell suspension was counted to determine both the total number of cells and to estimate viability through exclusion of trypan blue (Patterson, 1979).

Dye-recipient cells were plated 1-2 days prior to the assay in $60 \mathrm{~mm}$ tissue culture dishes (Corning) at a density of $10^{4} \mathrm{cells} / \mathrm{sq}$. cm. of growth surface. Dyedonors, at a density of $2,500 \mathrm{cells} / \mathrm{sq} . \mathrm{cm}$. of growth surface, were added to the unlabeled, dye-recipient cultures along with fresh medium, with or without (controls) a test substance. Depending on the experimental requirements, cultures were allowed $30 \mathrm{~min}$ to $5 \mathrm{~h}$ for donor cell attachment, spreading, and the opportunity to form permeable junctions. After co-culture the medium was aspirated and replaced with ice-cold PBSG with or without (controls) the test substance. The plates were then put on ice to retard establishment of additional dye-coupling.

Plates were scored for dye-coupling by examination of at least 100 contacting cell pairs at 400-fold magnification using a Nikon Diaphot-TMD microscope equipped with an epifluorescence unit. The donor-recipient cell pairs were first examined under bright-field conditions to verify their close association, and then under blue 
excitation (450-490 nm) for evidence of dye-coupling. Under light of this spectral band, the beads appeared as intensely bright dots which were clearly distinguishable from the DCCFDA-derived label. To evaluate changes in the frequency of dye-coupling, the percentage of contacting donor-recipient cells that showed evidence of dye-coupling was compared to control cultures.

Autoradiographic Visualization of Radiolabelled Nucleotide Transfer. Radionuclide-donor cells were labeled for $4 \mathrm{~h}$ in PBSG containing both ${ }^{3} \mathrm{H}$-uridine (10 uCi/ml) and fluorescent latex beads $\left(1-2 \times 10^{8}\right.$ beads/sq. cm. growth surface). Similar to the dye-coupling assay, the cells were then seeded into cultures of unlabeled recipient cells. After $1-5 \mathrm{~h}$ of co-culture the medium was aspirated, and each plate was rinsed with DPBS and placed on ice. The cultures were fixed with ice-cold $7 \%$ trichloroacetic acid for $30 \mathrm{~min}$, rinsed twice with icecold $7 \%$ trichloroacetic acid, once with distilled water and air dried. The plates were coated with Kodak NTB2 emulsion, air dried and exposed for 7-10 days in the dark. The plates were developed using Kodak D19, rinsed with distilled water, fixed with Kodak acid fixer, rinsed with tap water, post-stained with hematoxylin and eosin, and examined under a $50 \%$ ( $/ \mathrm{v})$ mixture of glycerol and DPBS.

Incorporation of Acid-Insoluble Radiolabel. To monitor RNA synthesis, cultures grown in $16 \mathrm{~mm} \mathrm{multi-}$ well dishes were incubated for $3.5 \mathrm{~h}$ with $5 \mathrm{uci} / \mathrm{mI}{ }^{3} \mathrm{H}-$ uridine. To monitor protein synthesis, the actinomycin-D treated cultures were incubated for $3.5 \mathrm{~h}$ in $60 \mathrm{~mm}$ dishes with $8 \mathrm{uCi} / \mathrm{ml}{ }^{3} \mathrm{H}$-leucine, and the cycloheximide treated cultures were incubated for $3.5 \mathrm{~h}$ in $35 \mathrm{~mm}$ dishes with 25 uCi/ml ${ }^{3} \mathrm{H}-$ leucine. The radionuclidelabeled cells were rinsed with ice-cold PBS, placed on ice and fixed with trichloroacetic acid as described for autoradiography. An alternate fixation protocol utilized a freshly prepared mixture of methanol and acetic acid (3:1) for $15 \mathrm{~min}$ (Stein and Yanishevsky, 1979). The cytoskeleton and other macromolecules were dissolved by incubation for $16-18 \mathrm{~h}$ in $0.1 \mathrm{~N} \mathrm{NaOH}$ at $37^{\circ} \mathrm{C}$. The $\mathrm{pH}$ was adjusted to neutrality by addition of an equal volume of $0.1 \mathrm{~N} \mathrm{HCl}$, the contents were mixed thoroughly, and the mixture was allowed to stand at room temperature for at least $2 \mathrm{~h}$. Triplicate samples were counted in a Beckman LS8000 scintillation counter to determine acid-insoluble radioactivity.

DNA Quantification. DNA was quantified with ethidium bromide using a modification of the method of Le Pecq and Paoletti (1966, 1967). Briefly, triplicate samples 
from each plate were mixed with ethidium bromide dissolved in a Tris/EDTA solution to provide final concentrations of $10 \mathrm{ug} / \mathrm{ml}$ ethidium bromide, $160 \mathrm{mM}$ Tris and $16 \mathrm{mM}$ EDTA. Fluorescence at $612 \mathrm{~nm}$ was measured on a fluorescence spectrophotometer using $306 \mathrm{~nm}$ excitation wavelength and compared to a control curve generated with calf thymus DNA dissolved in $0.1 \mathrm{~N} \mathrm{NaOH}$. The standard curve for the controls always had a correlation coefficient greater than 0.99 .

Statistical Methods. Growth curve data were analyzed using a two-factor analysis of variance (ANOVA), followed by Tukey's method for multiple comparisons (Devore, 1982). other data were analyzed using the Kruskal-Wallis or chi-square test for homogeneity, as appropriate, followed by post-hoc group comparisons using the methods described in Devore (1982).

\section{RESULTS}

Dye coupling. The dye chosen for this assay, DCCFDA, was of low toxicity to the SK-UT-1 cells as indicated by DNA measurements. Concentrations of DCCFDA below 25 uM did not alter DNA content at $2 \mathrm{~h}, 2$ days and 5 days post-treatment (Fig. 1). A significant reduction in growth rate occurred only at the highest concentration tested, $100 \mathrm{uM}(\mathrm{p}<0.001)$. The labeling treatment selected for use with SK-UT-1 cells in this assay, $15 \mathrm{uM}$ DCCFDA for $10 \mathrm{~min}$, allowed adequate detection of dyecoupling with no apparent toxicity.

Dye-coupling was readily detected by the presence of fluorescent dye in the bead-free recipient cells that were in contact with bead- and fluorescent dye-labeled donor cells (Fig. 2). Pre-plating the recipient cells a day or two in advance allowed unambiguous interpretation of dye-coupling, since the recipients were maximally flattened and had often replicated to form small colonies. In such cases, the dye was often distributed throughout the entire group of inter-connected cells from a single donor cell. The percent of dye-coupled cell pairs increased in proportion to the duration of co-culture until about $3-3.5 \mathrm{~h}$ (Fig. 3). Since no further increase in dye-coupling was observed with additional incubation up to $4.5 \mathrm{~h}, 3.5 \mathrm{~h}$ was selected as an optimal duration of culture for the experiments with the test substances, actinomycin-D and cycloheximide.

In order to compare the dye-coupling assay used in these investigations to a standard published procedure for junctional communication, parallel autoradiographic studies were performed using transfer of radiolabelled nucleotide (Pitts and simms, 1977). This procedure has 
been reported to be a highly sensitive method to study intercellular communication (Pitts and Kam, 1985).

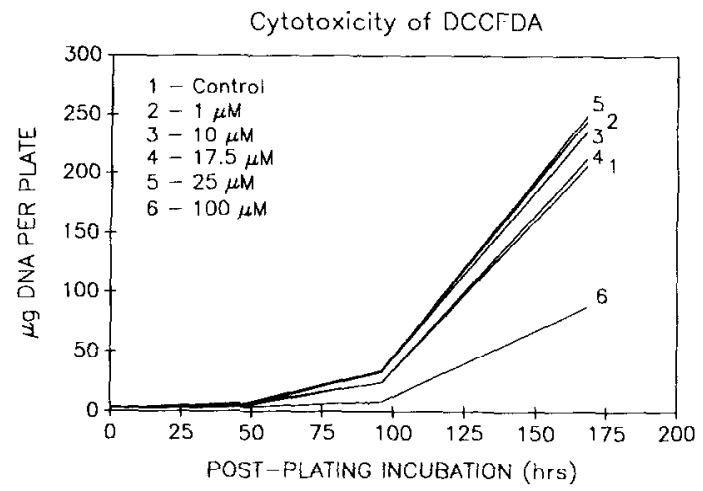

Fig. 1: Cytotoxicity of DCCFDA. Aliquots of freshly harvested SK-UT-1 cells were suspended in PBSG containing DCCFDA at a concentration of 0 (Control), 1,10 , $17.5,25$ or $100 \mathrm{uM}$. The cells were incubated for $5 \mathrm{~min}$ at ambient temperature, pelleted and rinsed with PBSG. Each pellet was resuspended in medium, and aliquots of the cell suspension were added to $35 \mathrm{~mm}$ wells of 6-well plates. At 2, 48, 96 and $168 \mathrm{~h}$ post-plating, three plates from each group were processed for quantification of DNA using ethidium bromide. A large reduction in DNA was evident only at $100 \mathrm{uM}(p<0.001)$.

The results in Figure 4 show that this dye-coupling assay provided results of comparable sensitivity.

Transcriptional Inhibition. To evaluate the importance of transcription on the development of dye-coupling, cultures were treated with actinomycin-D, a potent transcriptional inhibitor (Takusagawa et al., 1982). Actinomycin-D had no significant effect on dyecoupling, even though RNA synthesis was reduced in a concentration-dependent manner with treatments from 0.1 to $10 \mathrm{uM}$, as measured by the incorporation of acidinsoluble ${ }^{3} \mathrm{H}$-uridine (Table I). At the two highest concentrations tested, 5 and $10 \mathrm{uM}$ actinomycin-D, incorporation of acid-insoluble ${ }^{3} \mathrm{H}$-uridine was reduced to $1 \%$ of controls, yet dye-coupling was still $92 \%$ and $80 \%$ of controls, respectively. Actinomycin-D did not alter cell attachment as measured by DNA content, nor did it inhibit total protein synthesis at concentrations up to 10 $\mathrm{uM}$, as measured by incorporation of acid-insoluble ${ }^{3} \mathrm{H}-$ leucine (data not shown). The lack of an effect on total 
protein synthesis may be due to stabilization of existing mRNA, allowing normal rates of translation in spite
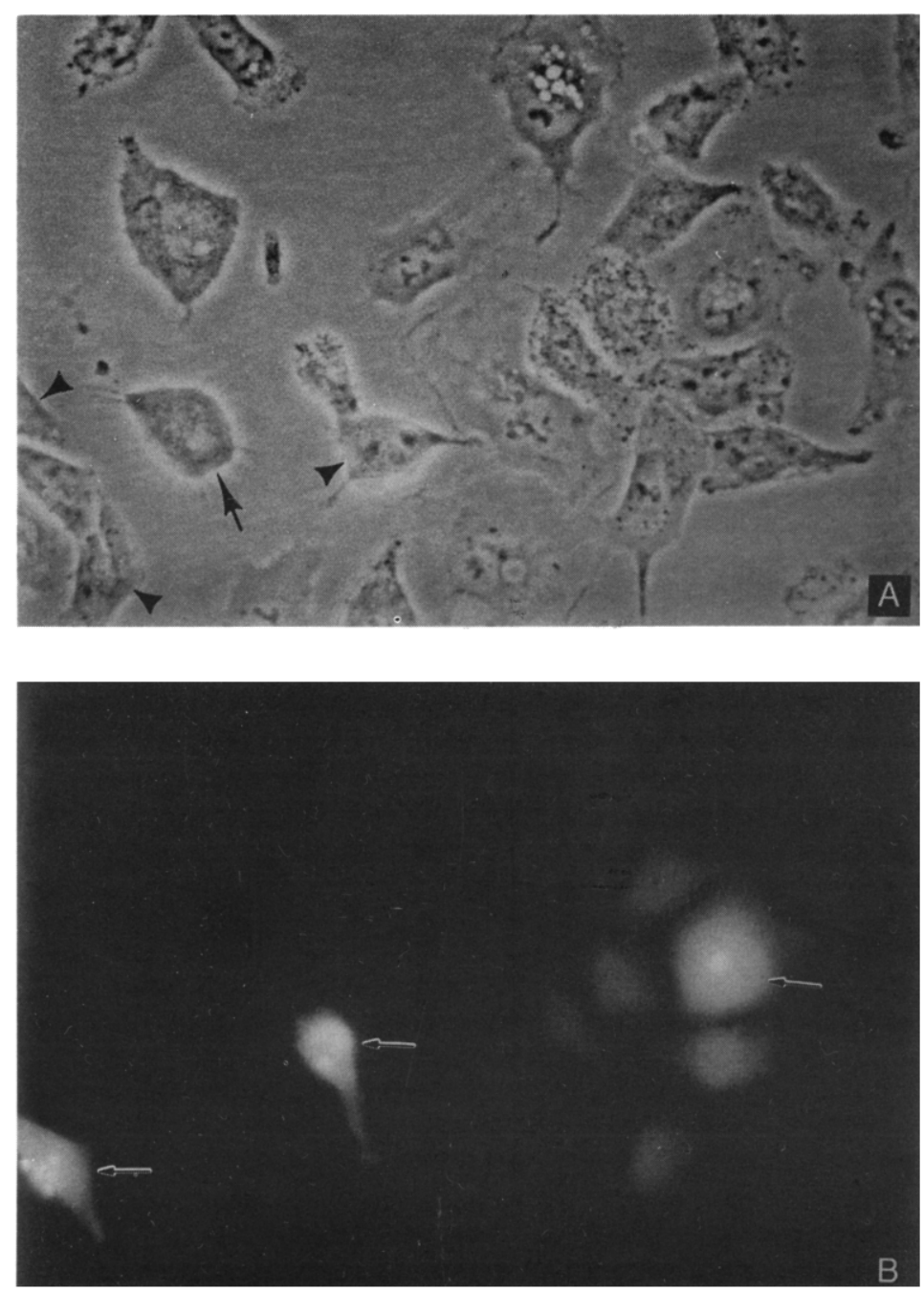

Fig. 2: Dye-coupling in SK-UT-l cells, (A) phasecontrast and (B) dark field. Donor cells (B, small arrows) were labeled with both fluorescein-conjugated latex beads and DCCFDA, then co-cultured with unlabeled cells. At $3.5 \mathrm{~h}$ post-plating, the culture was examined for evidence of dye-coupling. Extensive dye-coupling is sown between donor and recipient cells (B, right side), as well as the lack of dye-coupling to several contacting unlabeled cells ( $A$, arrowheads, compared to $B$, dark field). Note also the absence of dye in a non-contacting unlabeled cell (A, large arrow). X360. 
Time Course of Radiolabel Coupling in SK-UT-1 Cells

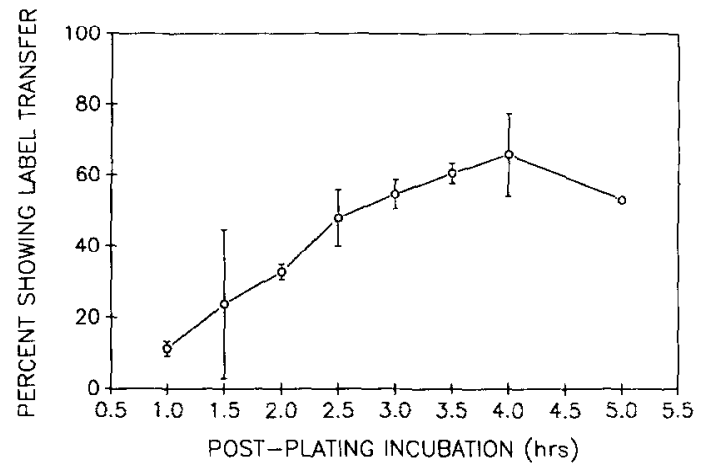

Fig. 3: Time Course of Dye-Coupling in SK-UT-1 Cells. The frequency of dye-coupling between SK-UT-1 cells increased in a time-dependent manner until about $3.5 \mathrm{~h}$ post-plating. Donor cells were labeled with latex beads and DCCFDA, then co-cultured with unlabeled cells. At various times after plating the donor cells, cultures were examined for evidence of dye-coupling. The data are compiled from five experiments, and represent the means $\pm S E$ from two to six cultures at each point except for the $4.5 \mathrm{~h}$ point, which represents a single culture.

of blocked transcription (Raghow, 1987). These experiments demonstrated that dye-coupling was established in this assay independent of active transcription.

Translational Inhibition. The importance of translation was evaluated in cultures treated with the protein synthesis inhibitor, cycloheximide (obrig et al., 1971). As expected, cycloheximide suppressed protein synthesis as measured by the incorporation of ${ }^{3} \mathrm{H}-1$ eucine into acid insoluble material (Table II). At the lowest concentration, $0.1 \mathrm{uM}$ cycloheximide, incorporation of acid-insoluble ${ }^{3} \mathrm{H}-$ leucine was reduced to $27 \%$ of controls $(p<0.05)$, with maximal reduction to $12 \%$ of controls at 1 $\mathrm{mM}(\mathrm{P}<0.001)$. The reduction of protein synthesis produced by cycloheximide treatment was rapid, since inhibition of $3 \mathrm{H}$-leucine incorporation was comparable whether ${ }^{3} \mathrm{H}$-leucine was added at the time of donor cell plating or following $0.5,1$ or $2 \mathrm{~h}$ post-plating (data not shown).

As shown in Table II, cycloheximide did not significantly alter dye-coupling at concentrations up to 1 uM, although considerable (73-81\%) inhibition of ${ }^{3} \mathrm{H}-$ leucine incorporation was observed at these concentrations. 


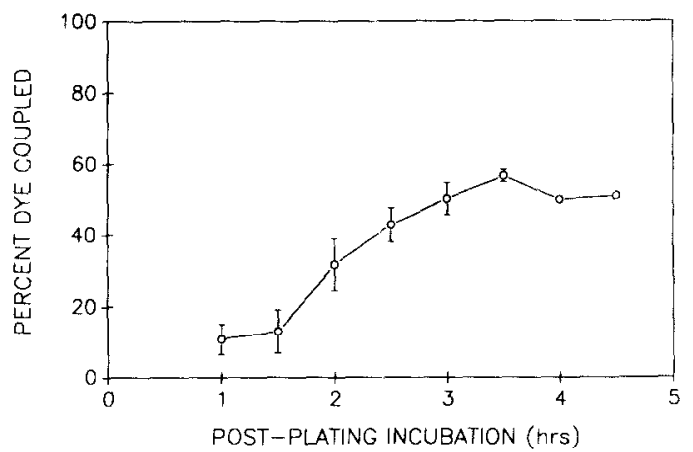

Fig. 4: Time Course of Radiolabel coupling in SK-UT-1 Cells. The frequency of radiolabel transfer between sKUT-1 cells increased in a time-dependent manner until about $4 \mathrm{~h}$. Donor cells were labeled with latex beads and ${ }^{3} \mathrm{H}$-uridine as described in Methods, then co-cultured with unlabeled cells. At various times after plating the donor cells, cultures were fixed and processed for autoradiography. The data are compiled from three experiments, and represent the means $\pm S E$ from two to three cultures at each point except for the $5 \mathrm{~h}$ point, which represents a single culture.

However, dye-coupling was inhibited in a concentrationdependent manner at higher concentrations of 10-1000 uM cycloheximide despite the fact that further inhibition of total protein synthesis was minimal at these higher concentrations, being reduced from $81 \%$ at 1 UM to $89 \%$ at $1 \mathrm{mM}$. Transcriptional effects of cycloheximide were also evaluated by measuring incorporation of ${ }^{3} \mathrm{H}$-uridine into acid-insoluble material. In these experiments it was observed that treatment with cycloheximide reduced ${ }^{3} \mathrm{H}$-uridine incorporation in a concentration-dependent manner over the range tested, 1 to $100 \mathrm{uM}(p<0.05$; Table II). No cycloheximide effects on cell attachment were noted by measures of DNA content (data not shown). 
TABLE I. THE EFFECT OF ACTINOMYCIN-D ON RNA SYNTHESIS AND DYE-COUPLING ${ }^{a}$

\begin{tabular}{|c|c|c|c|}
\hline $\begin{array}{l}\text { Actinomycin-D } \\
\text { (uM) }\end{array}$ & $\begin{array}{l}\text { Acid-Insoluble } \\
{ }^{3} \text { H-Uridine (dpn }\end{array}$ & n/ug DNA) & $\begin{array}{l}\text { Dye- } \\
\text { Coupling } \\
\text { (\% Control }\end{array}$ \\
\hline 0 & $37,030 \pm 2915^{b}$ & $(100 \%)$ & $100^{\mathrm{C}}$ \\
\hline 0.1 & $6,943+229$ & $(19 \%)^{e}$ & $\begin{array}{l}109 \\
103\end{array}$ \\
\hline 0.5 & $3,088 \pm 107$ & $(8 \%)^{e}$ & 98 \\
\hline 1 & $1,799+92$ & $(58)^{e}$ & 83 \\
\hline 5 & $362+40$ & $(1 \%)^{e}$ & 92 \\
\hline 10 & $209 \pm 15$ & $(1 \%)^{e}$ & 80 \\
\hline
\end{tabular}

a Incorporation of ${ }^{3} \mathrm{H}$-uridine into acid-insoluble material and dye-coupling were performed in parallel cultures as described in Materials and Methods, $3.5 \mathrm{~h}$ after co-culture of donors and recipients.

$b$ Each value is the mean $\pm \mathrm{SE}$ ( $\%$ control) of triplicate samples taken from each of four cultures.

C Each value represents 100 donor-recipient cell pairs from single cultures except for controls which were done in duplicate. The unadjusted mean $\pm \mathrm{SE}$ of dye-coupling in the controls was $37 \pm 9 \%$. Data from one experiment are shown, although similar experiments verified the results.

d n.d., not determined.

e significantly less than control and all other exposures $(p<0.001)$.

\section{DISCUSSION}

This dye-coupling assay provides a relatively rapid, simple, and inexpensive method to investigate gap junction-mediated intercellular communication. Comparisons with similarly-modelled autoradiographic experiments demonstrated that this assay is of comparable sensitivity, avoids the use of potentially hazardous radiochemicals, and is significantly more rapid. Likewise, there are several advantages to the use of this assay as compared to dye-coupling assays that use microinjection of fluorescent dyes. Since DCCFDA is fluorescent only after metabolic cleavage of the ester sidechains, it provides a measure of viability of the dyedonor cells (Rotman and Papermaster, 1966). Similarly, 
Table II. THE EFFECT OF CYCLOHEXIMIDE ON PROTEIN SYNTHESIS, RNA SYNTHESIS AND DYE-COUPLING ${ }^{a}$

\begin{tabular}{|c|c|c|c|}
\hline $\begin{array}{l}\text { Cyclo- } \\
\text { heximide } \\
\text { (uM) }\end{array}$ & $\begin{array}{l}\text { Acid-Insoluble } \\
{ }^{3} \text {-Leucine } \\
\text { (dpm/ug DNA) }\end{array}$ & $\begin{array}{l}\text { Acid-Insoluble } \\
3_{\text {H-Uridine }} \\
\text { (dpm/ug DNA) }\end{array}$ & $\begin{array}{l}\text { Dye- } \\
\text { Coupling } \\
\left(\frac{f}{} \text { Control) }\right.\end{array}$ \\
\hline 0 & $\begin{array}{c}11,992 \pm 2,159^{b} \\
(1008)\end{array}$ & $\begin{array}{c}32,492 \pm 1,912^{\mathrm{b}} \\
(100 \%)\end{array}$ & $100^{c}$ \\
\hline 0.1 & $\begin{array}{c}3,254 \pm 387^{d} \\
(27 \%)\end{array}$ & n.d.e & 113 \\
\hline 0.5 & $\begin{array}{c}2,813 \pm 964^{d} \\
(24 \%)\end{array}$ & n.d. & 89 \\
\hline 1 & $\begin{array}{c}2,282 \pm 263 \mathrm{f} \\
(19 \%)\end{array}$ & $28,085 \pm 1,820^{d}$ & 94 \\
\hline 10 & $\begin{array}{c}1,762 \pm 1659 \\
(15 \%)\end{array}$ & $23,158 \pm 1,4149$ & $60^{9}$ \\
\hline 100 & $\begin{array}{c}2,092 \pm 5119 \\
(17 \%)\end{array}$ & $\begin{array}{c}18,266 \pm 569 \\
(56 \%)\end{array}$ & 509 \\
\hline 1000 & $\begin{array}{c}1,433 \pm 299 \\
(12 \%)\end{array}$ & n.d. & 319 \\
\hline
\end{tabular}

a Incorporation of ${ }^{3} \mathrm{H}$-leucine into acid-insoluble material and dye-coupling were performed in parallel cultures and incorporation of ${ }^{3} \mathrm{H}$-uridine was performed in a separate experiment; measurements were made $3.5 \mathrm{~h}$ after co-culture of donor and recipient cells.

$\mathrm{b}$ Each value is the mean $\pm \mathrm{SE}$ ( $\%$ control) of triplicate samples from each of two or three cultures.

C Each value represents 100 donor-recipient cell pairs from single cultures except for controls which were done in duplicate. The unadjusted mean $\pm \mathrm{SE}$ of dye-coupling in the controls was $62 \pm 1 \%$. Data from one experiment are shown; similar experiments verified the results.

d Significantly less than control $(p<0.05)$.

e n.d., not determined.

f Significantly less than control $(p<0.01)$.

9 Significantly less than control $(p<0.001)$. 
because a relatively early event after cell death is the loss of membrane integrity with consequent loss of lowmolecular weight materials (Patterson, 1979), overt toxicity can be readily observed by the presence of bead-labeled cells that lack fluorescent dye. Other advantages include the ability to perform the assay without requiring special skills or equipment, beyond basic tissue culture techniques and an inverted fluorescence microscope.

Since the donor cells must attach to the substratum, spread out, recognize adjacent recipient cells, and form communicating junctions before successful dyecoupling can be observed, the ultimate expression of dye-coupling is dependent on the events that occur in the early establishment of junctional communication (Burger and Misevic, 1985). Our experiments with inhibitors of transcription (actinomycin-D) and translation (cycloheximide) investigated the importance of protein synthesis in these early events.

Actinomycin-D inhibited transcription by more than 98\% but did not significantly alter dye-coupling, providing clear evidence that active transcription is not required for cells to establish dye-coupling under the conditions of this assay. Dye-coupling was not inhibited by cycloheximide treatments of 1 uM or lower, despite considerable suppression of protein synthesis at these concentrations. While higher concentrations of cycloheximide did reduce dye-coupling, this effect occurred with relatively slight further reductions in protein synthesis. These data suggest that the reduced dyecoupling observed at higher concentrations of cycloheximide may be due to some effect of cycloheximide other than inhibition of protein synthesis. Although cycloheximide partially inhibited transcription in addition to its effects on translation, the absence of a significant effect on dye-coupling by actinomycin-D suggests that transcriptional inhibition did not contribute to cycloheximide's effect on dye-coupling.

The data from these experiments suggest that the development of junctional communication in this assay may depend on pre-existing protein. This mechanism is supported by reports that some cells in vitro can form gap junctions within minutes of contact (Johnson et al., 1974; Epstein et al., 1977; Dahl et al., 1980; Campbelí and Albertini, 1981; Kachar and Reese, 1985), in some cases unaffected by treatments with protein synthesis inhibitors (Epstein et al., 1977, Cox et al., 1976). In experiments with mouse embryos and frog larvae, gap junction development was inhibited by treatment with transcription and translation inhibitors, but only if the treatments began early enough in development (Decker, 1976; Mclachlin et al., 1983; Levy et al., 1986; 
McLachlin and Kidder, 1986). Finally, the observation that cytoplasts are able to communicate effectively many hours after cell enucleation provides support that transcription and/or translation of proteins is not required for establishment of junctional communication in all cases (Cox et al., 1976; Bols and Ringertz, 1979).

In summary, we have developed a rapid, simple and sensitive dye-coupling assay which should prove useful as a method to detect changes in junction-mediated intercellular communication. The data from the present experiments suggest that neither active transcription nor translation is absolutely necessary for the establishment of dye-coupling in this system. This assay has been successfully adapted to other cell types in our laboratory (Loch-Caruso et al., 1989; Loch-Caruso, 1990).

\section{ACKNOWLEDGEMENTS}

The authors acknowledge the assistance of Dr. Michael Welsh for critically reviewing a draft of this manuscript, as well as the assistance of David Hunsche and Mary Weed with the graphics preparation and photography. The authors also thank Dr. Warren $\mathrm{Ku}$ for assistance with the autoradiography, Susan Friedman and Madeleine Cimini for helpful discussions, and Suzan cull for secretarial assistance. This research was conducted as partial fulfillment of the doctoral dissertation of B.Z., and was supported, in part, by a predoctoral training grant to B.Z. (NIH \#ES07062) and with grants to R.L.-C. from the March of Dimes (15-79), NIH (ES04424), and NIOSH (OHOOO59). Additional support and assistance were provided by the Laboratory Animal core of the Reproductive Sciences Program (NIH \#HD18258).

\section{REFERENCES}

Bols, N. C. and Ringertz, N. R. (1979) A study of metabolic cooperation with established myoblast cell lines. Exp. Cell Res. 120:15-23.

Burger, M. M. and Misevic, G. (1985) Cell encounter: molecular and biological aspects of initial contacts. in: Marthy, H. -J. (ed.). Cellular and molecular control of direct cell interactions. New York: Plenum Press.

Campbell, K. L. and Albertini, D. F. (1981) Freezefracture analysis of gap junction disruption in rat ovarian granulosa cells. Tissue \& Cell 13:651-668. 
Chen, T. R. (1977) In situ detection of mycoplasma contamination in cell cultures by fluorescent Hoechst 33258 stain. Exp. Cell Res. 104:255-262.

Cox, R. P., Krauss, M. R., Balis, M. E. and Dancis, J. (1976) Studies on cell communication with enucleated human fibroblasts. J. Cell Biol. 71:693-703.

Dahl, G., Azarnia, R. and werner R. (1980) De novo construction of cell-to-cell channels. In Vitro 16:10681075 .

Decker, R. S. (1976) Hormonal regulation of gap junction differentiation. J. Cell Biol. 69:669-685.

Devore, J. (1982) Probability and statistics for engineering and the sciences. Monterey, CA: Brooks/Cole Publishing Co. pp.287-289, 371-393, 541-551, 596-598.

Eagle, H. (1959) Amino acid metabolism in mammalian cell cultures. Science 130:432-437.

Epstein, M. L., Sheridan, J. D. and Johnson, R. G . (1977) Formation of low-resistance junctions in vitro in the absence of protein synthesis and ATP production. Exp. Cell Res. 104:25-30.

Fogh, J., Fogh, J. M. and orfeo, T. (1977) one hundred and twenty-seven cultured human tumor cell lines producing tumors in nude mice. J. Nat. Cancer Inst. 59:221225 .

Garfield, R. E. (1988) structural and functional studies of the control of myometrial contractility and labor. in: McNellis, D., Challis J., MacDonald, P., Nathanielsz, P. and Roberts, J. (eds.). The onset of labor: Cellular \& integrative mechanisms. Ithaca, NY: Perinatology Press.

Johnson, R., Hammer, M., Sheridan, J. and Revel, J.-P. (1974) Gap junction formation between reaggregated novikoff hepatoma cells. Proc. Natl. Acad. Sci. USA $71: 4536-4540$.

Kachar, B. and Reese, T. S. (1985) Rapid formation of gap-junction-like structures induced by glycerol. Anat. Rec. $213: 7-15$.

Larsen, W. J. (1983) Biological implications of gap junction structure, distribution and composition: a review. Tissue \& Cell 15:645-671. 
Le Pecq, J.-B. and Paoletti, C. (1966) A new fluorometric method for RNA and DNA determination. Anal. Biochem. $17: 100-107$.

Le Pecq, J.-B. and Paoletti, C. (1967) A fluorescent complex between ethidium bromide and nucleic acids. Physical-chemical characterization. J. Molec. Biol. $27: 87-106$.

Levy, J. B., Johnson, M. H., Goodall, H. and Maro, B. (1986) The timing of compaction: Control of a major developmental transition in mouse early embryogenesis. J. Embryol. exp. Morph. 95:213-237.

Loch-Caruso, R. (1989) Application of cell-cell communication assays to problems of developmental toxicology. in: Kimmel, G. and Kochhar, D. (eds.). In vitro techniques in developmental toxicology: use in defining mechanisms and risk parameters. Boca Raton, FL: CRC Press.

Loch-Caruso, R., Caldwell, V., Cimini, M. and Juberg, D. (1988) Comparison of assays for gap junctional communication using human embryocarcinoma cells exposed to dieldrin. Fundam. Appl. Toxicol., in press.

Loewenstein, W. R. (1981) Junctional intercellular communication: the cell-to-cell membrane channel. Physiol. Rev. 61:829-913.

Mclachlin, J. R., Caveney, S. and Kidder, G. M. (1983) Control of gap junction formation in early mouse embryos. Dev. Biol. 98:155-164.

McLachlin, J. R. and Kidder, G. M. (1986) Intercellular junctional coupling in preimplantation mouse embryos: effect of blocking transcription or translation. Dev. Biol. 117:146-155.

Obrig, T. G., Culp, W. J., McKeehan, W. L. and Hardesty, B. (1971) The mechanism by which cycloheximide and related glutaramide antibiotics inhibit peptide synthesis on reticulocyte ribosomes. J. Biol. Chem. 246:174-181.

Patterson, M. K., Jr. (1979) Measurement of growth and viability of cells in culture. in: Jakoby, $W$. and Pastan, I. (eds.). Methods in enzymology. Vol. 58. New York: Academic Press. 
Pitts, J. D. and Kam, E. (1985) Communication compartments in mixed cell cultures. Exp. Cell Res. 156:439449 .

Pitts, J. D. and Simms, J. W. (1977) Permeability of junctions between animal cells. Intercellular transfer of nucleotides but not of macromolecules. Exp. Cell. Res. 104:153-163.

Raghow, R. (1987) Regulation of messenger RNA turnover in eukaryotes. Trends Biochem. Sci. 12:358-360.

Rotman, B. and Papermaster, B. W. (1966) Membrane properties of living mammalian cells as studied by enzymatic hydrolysis of fluorogenic esters. Proc. Natl. Acad. Sci. USA 55:134-141.

Takusagawa, F., Dabrow, M., Neidle, S. and Berman, H. (1982) The structure of a pseudo-intercalated complex between actinomycin and the DNA binding sequence $d(G P C)$. Nature 296:466-469.

Paper received 06.04.90. Paper accepted 02.05.90. 